\title{
Personality and Creativity: A Study in Spanish-Speaking Children
}

\author{
Personalidad y Creatividad: un estudio en niños de habla hispana
}

Gabriela Krumm $^{12 *}$, Viviana Lemos ${ }^{12}$ and María Cristina Richaud ${ }^{12}$

\begin{abstract}
This work aimed at studying the relationship between personality from the Big Five Personality model and creativity through different techniques (i.e., a paper and pencil task, and scales) and informants (i.e., the child and parents). We evaluated a sample of 359 Spanish-speaking school children of both genders, aged 9 to 13 years. Personality was assessed with the Argentine Questionnaire of children's Personality (CAPI). Creativity was evaluated using the following instruments: The Torrance Test of Creative Thinking-Figural Form B; and the Creative Personality Scale (EPC). Pearson correlations and multiple linear regressions consistently showed that Neuroticism related negatively to creativity while competence has a positive relation. The results suggested that more creative children presented less vulnerability, irritability and psychological distress, eventually becoming more independent, competent and emotionally self-regulated in coping with environmental demands.

Resumen

Este trabajo tuvo como objetivo estudiar la relación entre la personalidad desde el modelo de los Big Five y la creatividad a través de diferentes técnica (i.e., tareas de papel y lápiz, y escalas) e informantes (i.e., niños y padres). Se evaluó una muestra de 359 escolares hispano hablantes de ambos sexos, de 9 a 13 años de edad. La personalidad fue evaluada con el Cuestionario Argentino de Personalidad Infantil (CAPI). La creatividad fue evaluada usando los siguientes instrumentos: la prueba de figuras del Test de Pensamiento Creativo de Torrance, Forma B (TTCT), y la Escala de Personalidad Creadora (EPC).Las correlaciones de Pearson y las regresiones lineales múltiples demostraron consistentemente que el Neuroticismo se relaciona negativamente con la creatividad, mientras que la faceta de la competencia lo hace positivamente. Los resultados sugieren que los niños más creativos presentarían menos vulnerabilidad, irritabilidad y angustia psicológica siendo más independientes, competentes y emocionalmente autorregulados para hacer frente a las demandas ambientales.
\end{abstract}

\section{Keywords}

personality; creativity; big five; children

Palabras Clave

personalidad; creatividad; big five; niños

${ }^{1}$ Centro Interdisciplinario de Investigaciones en Psicología Matemática y Experimental (CIIPME) del Consejo Nacional de Investigaciones Científicas y Técnicas (CONICET), Argentina.

2Universidad Adventista del Plata (UAP), Argentina

*Corresponding author: Centro de Investigación en Psicología y Ciencias Afines de la Universidad Adventista del Plata, Cervantes 70 , (E3103XAF), Libertador San Martín, Entre Ríos, República Argentina. Phone: (54-011) 343 4918000-1308. gabrielakrumm@doc.uap.edu.ar Manuscript received 19-02-2017; revised 04-04-2017; accepted 15-05-2017.

\section{Introduction}

There is evidence that creativity and personality have something in common: both emphasize the subject as a whole (Feist, 1998). The essence of the most creative individuals is the singularity of their behavior and ideas, and creativity and personality studies are both oriented to the stability and consistency of these distinctive features. Research on person- ality and creativity encompasses various fields, professions and age groups that use diverse definitions of constructs and different procedures to evaluate them. This diversity of studies makes the identification of the creative personality a particularly complex task (Batey \& Furnham, 2006), and becomes difficult to specify the traits of creative adults (López Martínez \& Navarro Lozano, 2010), much more those of children.

Many of the differences found in personality traits as- 
sociated with creativity may be due to the use of different theoretical frameworks for the study of personality. Currently, trait approach (Simkin \& Etchevers, 2014) is one of the most commonly used frameworks. Traits are described as a relatively stable and lifelong pattern of thoughts, emotions and behaviors (Costa \& McCrae, 1980).

Although there are different models that have attempted to classify the multiplicity of traits in different categories (e.g. Cattell, 1950; Eysenck, 1976), the Model of Five Factors (FFM; Costa \& McCrae, 1980) presently stands out among those which have gained increasing acceptance in the academic field (Depaula \& Azzollini, 2013).

\section{Personality and creativity in adults}

As regards the relationship between the Big Five and creativity, it has been found that the most consistent results come from the positive association of Openness and Extraversion with creativity (Hughes, Furnham, \& Batey, 2013).

Several studies have shown that Openness predicts the creativity of youth and adults in different domains -including the arts, sciences, and humanities (Feist, 1998) and at different levels of analysis -which involve divergent thinking, thinking style, goals and creative work, pastimes, accomplishments and creative products (Batey \& Furnham, 2006; Dollinger, Urban, \& James, 2004; Kaufman et al., 2015; Silvia, Kaufman, \& Pretz, 2009; Silvia, Nusbaum, Berg, Martin, \& O’Connor, 2009).

Some studies demonstrated that Extraversion showed a positive correlations with creativity (Dollinger et al., 2004; Hoseinifar et al., 2011). Specifically, this factor seems to be a positive predictor of self-rated creativity (Furnham, Hughes, \& Marshall, 2013), perceived creativity in performance, interpersonal creativity, and artistic and general creativity (Davis, Kaufman, \& McClure, 2011; Werner, Tang, Kruse, Kaufman, \& Spörrle, 2014).

As for the remaining factors, (i.e., Conscientiousness, Neuroticism, and Agreeableness) the results have been more ambiguous and complex (Hughes et al., 2013; Reiter-Palmon, Illies, \& Kobe, 2009; Silvia \& Kimbrel, 2010).It has been found that Neuroticism is a positive predictor of artistic creativity but a negative predictor of scientific and daily creativity (Batey \& Furnham, 2006) as well as divergent thinking (Chamorro-Premuzic \& Reichenbacher, 2008). Finally, Batey, Chamorro-Premuzic, and Furnham (2010) specifically found that the facet vulnerability of Neuroticism was a negative predictor of ideational behavior. Conscientiousness showed a negative relationship with verbal, pictorial and artistic creativity but a positive correlation with daily and scientific creativity (Batey \& Furnham, 2006). Finally, Agreeableness was a negative predictor of creative achievement in scientists and artists (Feist, 1998) and a positive predictor of daily creativity, self-rated creativity, and creativity from a divergent thinking perspective (Batey \& Furnham, 2006; Silvia, Nusbaum, et al., 2009).

\section{Personality and creativity in children}

Regarding creativity in children, it has been suggested that only adults are capable of creative performance, whereas children merely show creative potential (Sternberg \& Lubart, 1997) due to their constant intellectual, emotional, social and motor changes that influence the development of creativity. This fact would probably explain why studies of personality and creativity in children are scarce. One work in this field is the one developed by De Caroli and Sagone (2009) who found that only the dimension of flexibility -measured by the Test of Creative Thinking- was moderately and negatively correlated with the factors of Conscientiousness, Emotional Instability, Energy and Agreeableness of the Big Five Questionnaire for Children (BFQ-C). It is noteworthy that there was no association between creativity and Openness. Furthermore, studies with a focus on Cattell's traits in school-age children showed an increase in creativity in children with selfrestraint, anxiety, extraversion, emotional stability, awareness, soft sensitivity, submission, security and an entrepreneurial attitude (López Martínez \& Navarro Lozano, 2010).

Though there are studies about the relationship between personality and creativity in Spanish- speaking children (Garaigordobil \& Pérez, 2002; Krumm, 2012), these are based on personality concepts different to the ones operationalized by the approach of the Big Five, with which studies are scarce or almost nonexistent, mainly in our context.

\section{The present research}

Based on the theoretical and empirical background previously described, the present study aims at exploring the relationship between personality based on the Big Five approach and creativity measured by different techniques (i.e., a paper and pencil task and scales) and informants (i.e., children and parents) in 9- to 13- year old children.

\section{Method}

\section{Participants}

The study has a correlational design. It was completed using a non-probabilistic sample of 359 school children from 9 to 13 years of age $(M=10.22 ; S D=1.20)$. The sample included $193(53.8 \%)$ female and $166(46.2 \%)$ male students in the fourth, fifth and sixth grades of primary school and the first year of secondary school. The children were from the cities of Libertador San Martin and Crespo in Entre Rios, Argentina.

\section{Measures \\ Argentine Children's Personality Questionnaire (Cuestionario Argentino de Personalidad Infantil CAPI)}

The CAPI was developed for Argentine children from 9 to 13 years of age and operationalizes the child's personality construct based on the Big Five approach (Costa \& McCrae, 1980). It is composed of 46 items based on a three-point Likert scale: (a) Yes, (b) Sometimes and (c) No. The completed psychometric analyses of the CAPI-the discriminative power 
Personality and Creativity: A Study in Spanish-Speaking Children (Research Article) -35

Table 1

Factors and facets of CAPI

\begin{tabular}{|c|c|c|c|c|}
\hline Neuroticism (N) & Extraversion (E) & Restraint $(\mathbf{R})$ & Meticulousness (M) & Openness $(\mathrm{O})$ \\
\hline Competence (-) & $\begin{array}{l}\text { Gregarious feeling and } \\
\text { positive emotions }\end{array}$ & Adaptability & Order & Action \\
\hline $\begin{array}{l}\text { Self-criticism } \\
\text { Vulnerability } \\
\text { Anxiety }\end{array}$ & Confidence & $\begin{array}{l}\text { Excitement-Seeking (-) } \\
\text { Activity (-) }\end{array}$ & $\begin{array}{l}\text { Organization } \\
\text { Responsibility }\end{array}$ & Innovation \\
\hline
\end{tabular}

Note: “-" represents a negative association between a facet and its overarching factor.

of the items, internal consistency, and factor analysis-have all been satisfactory (i.e., Grinhauz \& Solano, 2014). Table 1 shows the distribution of the personality factors and facets in the questionnaire.

An item for the Neuroticism factor (hereafter N) is: "I need someone to help me solve my problems (difficulties), however feeble." For the Meticulousness factor (hereafter M) an example is: "I like having all my things in place." For the Restraint factor (hereafter R) an instance is: "I like to get my way." An item for the Extraversion factor (hereafter E) is: "I like being among many people." Finally, for the Openness factor (hereafter $\mathrm{O}$ ) one of the item is: "I like learning new things."

Although CAPI was developed based on the Big Five approach, its operationalization showed a distribution of facets and factors different from that found in adults. This may be due to the fact that in children, the most temperamental aspects had more prevalence than those aspects developed from interaction with the environment. For instance, in adults Competence is a facet of the Conscientiousness factor - a dimension in which the environment exerts greater influence. However, in children, Competence seems to be correlated with the most temperamental aspects of personality, including the $\mathrm{N}$ factor (Lemos, 2013).

\section{The Figural Torrance Tests of Creative Thinking (TTCT), Form B}

This test consists of three 10 minute activities. Each task suggests a different phrase for prompting the construction of drawings or the completion of figures. Together, the activities assess Fluency, Originality, Elaboration, Abstractness of Title, and Resistance to Premature Closure (Torrance, Ball, \& Safter, 1992). The TTCT test also measures thirteen criteria termed creative strength or strong points of creativity (Torrance et al., 1992)The test scoring is either skill-based or based comprehensively on dimensions of creative strength, which is what we used in this study. A study of Argentine children and adolescents showed that the TTCT test has an internal consistency of .70 (Krumm \& Lemos, 2011a). With respect to construct validity, confirmatory factor analysis identified two correlated factors, Innovation and Adaptation. Innovation is composed of the Fluency and Originality skills, and Adaptation is composed of Elaboration, Resistance to Premature Closure and Ab-stractness of Title (Krumm, Lemos, \& Arán Filippetti,
2014).

\section{Creative Personality Scale (CPS) (Escala de Personalidad Creadora-EPC)}

The CPS aims at complementing other tests of creativity, such as those from the divergent thinking perspective. The CPS (developed and studied in Spain) consists of posing 21 statements about behaviors and creative personality traits and scaling the answers as "nothing", "something", "enough" or "a lot" $(0$ nothing and 3 a lot). Some examples of the scale items are: "I like playing fantasy, imaginative games," "I make up songs, verses, poems, and jokes," and "I build toys from materials that I have at hand." The CPS can be administered as a selfreport to children, parents and teachers in the hetero-report version (Garaigordobil \& Pérez, 2005). The self-report version is suggested for children over 10 years old due to the difficulty of the items. In this research, the scale was completed by children who attended sixth grade and the first year of high school, being $N=157$.

In this research context, the Kaiser-Meyer-Olkin index of sampling adequacy (KMO) was $.807\left(x^{2}(210)\right.$ the Bartlett $=$ $876,339, p<.001)$. The component was found to account for $25.1 \%$ of the variance. The total internal consistency of the scale was assessed by the Cronbach Alpha coefficient, obtaining a value of .84

Concerning the psychometric properties of the CPS heteroreport version, the KMO index of sampling adequacy was $.823\left(x^{2}(210)\right.$ the Bartlett $\left.=1051.060, p<.001\right)$. The com-ponent was found to account for $28.36 \%$ of the variance. The Cronbach Alpha obtained a value of .86 (Krumm \& Lemos, 2011b).

\section{Procedure}

This research project was approved by the Ethics Committee of the Centro Interdisciplinario de Investigaciones en Psicología Matemática y Experimental (CIIPME), CONICET. First, permission was requested from the principals of the schools and involved, and the characteristics of the research were explained to them. Next, the parents or legal guardians were sent a sealed manila envelope with the informed consent forms and CPS hetero-report for the guardian or parent (father or mother). 


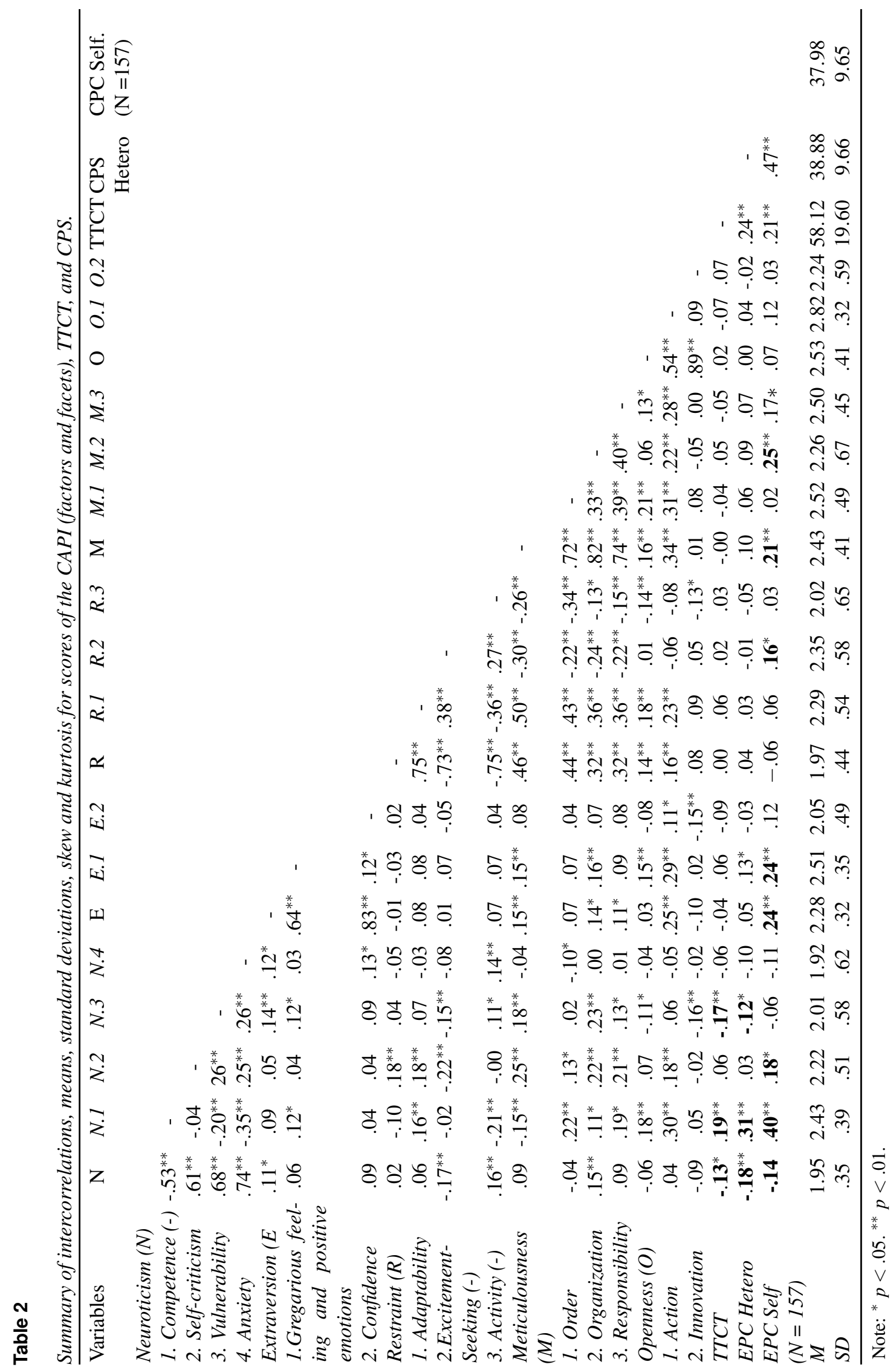


The informed consent form explained the objectives of the research and the types of tasks that would be developed in the class schedule, emphasizing that participation was voluntary and anonymous.

Finally, after receiving the signed consent forms, the evaluation was conducted within a classroom context: fourth and fifth graders completed the Figural TTCT, and children who attended sixth grade and the first year of high school completed the TTCT and the self-report CPS.

\section{Data analysis}

Descriptive analysis (means and standard deviations) of the variables involved in the study and analysis of Pearson correlation $(r)$ were performed. Multiple linear regression analysis was performed using the personality traits measured by the CAPI as predictors, and creativity was measured by the TTCT, and the self and hetero-report versions of the CPS as outcome variables.

\section{Results}

Table ?? shows the means, standard deviations and the correlations of the variables of this study. The results show low to moderate correlations between the variables included in this study.

\section{Personality and creativity from TTCT}

Table 2 shows the multiple regressions of CAPI factors and facets with measures of creativity.

It was explored through a multiple linear regression analysis whether personality factors relate to children's creativity evaluated by means of the TTCT figural test. There was no significant overall relationship between personality from the Big Five model and creativity $(F(5,351)=1.31 ; p=.258)$. However, as the Pearson's $(r)$ correlation analysis previously presented had suggested a negative and significant relationship $(p<.05)$ between the $\mathrm{N}$ factor and creativity as measured by the TTCT, we decided to perform a more detailed analysis considering the CAPI personality facets.

These facets, it was found that they account for 12 percent of the variance, being relevant $(F(14,355)=3.44 ; p<.001)$ the relationship among these facets and creativity. The standardized beta coefficients showed that both competence and self- criticism -facets from the $\mathrm{N}$ factor- positively predict creativity, whereas the vulnerability facet from the $\mathrm{N}$ factor and actions facet from the $\mathrm{O}$ factor predict it negatively (see Table 2).

\section{Personality and creativity from the CPS}

A multiple linear regression among the CAPI results and the assessment of creative personality by parents(see Table 2) showed that there is a significant overall relationship between personality from the Big Five model and the creative personality $(F(5,350)=3.83 ; p=.002)$. CAPI factors account for 5 percent of the variance, though to a limited extent. Stan- dardized beta coefficients showed that $\mathrm{M}$ positively predicted creative personality while $\mathrm{N}$ predicted it negatively.

Concerning the facets (see Table 2) were found to account for 14 percent of the variance, with a statistically significant relationship with creative personality based on parental assessment $(F(14,341)=3.82 ; p<.001)$. When analyzing the standardized beta coefficients, the competence facet from the $\mathrm{N}$ factor and the gregarious feeling and positive emotions facet from the E factor, positively predict the child's creative personality from parental assessment.

The multiple regression results obtained from CAPI as regards creative personality from the child's assessment (see Table 2) demonstrated the existence of a significant overall relationship between personality from the Big Five model and creative personality $(F(5,15)=4.67 ; p=.001)$. CAPI factors account for 14 percent of the variance. Standardized beta coefficients indicated that $\mathrm{E}$ and $\mathrm{M}$ positively predicted a creativity self-assessment, whereas $\mathrm{N}$ predicted it negatively. In terms of the facets (see Table 2), , it was found that they account for 32 percent of the variance, being significant the relationship among this facets and the self-assessment of creative personality $(F(14,140)=4.79 ; p<.001)$. Standardized beta coefficients showed that the competence and self- criticism facets from the $\mathrm{N}$ factor, the gregarious feeling and positive emotions facets from the $\mathrm{E}$ factor, the excitement seeking facet from the $\mathrm{R}$ factor and the organization facet from the $\mathrm{M}$ factor all positively predicted self-report of creativity.

\section{Discussion}

While there are numerous studies about the relationship between personality and creativity in adults, those related to children are still very scarce. Therefore, the aim of this study was to explore the relationship between the child's personality from the perspective of the Big Five approach and creativity assessed through different techniques and informant.

\section{Personality and Creativity from TTCT}

Analizing the facets of CAPI, the results showed that children with greater sense of competence (i.e., self confident and independent), less vulnerable (i.e., with greater ability to meet the environmental demands and pressures) and with more self-criticism seem to be more creative in paper and pencil tasks. Consistent with these results, De Caroli and Sagone (2009) found a negative relationship between emotional instability and creativity in Italian children. Moreover, studies in adults have also found that creative people show reduced vulnerability (Batey et al., 2010) and more emotional stability (Werner et al., 2014), independence, self-confidence (Barron \& Harrington, 1981), self-criticism and self-demandingness (López Martínez \& Navarro Lozano, 2010; Rodríguez Estrada, 2005).

Contrary to expected, there was not a positive relationship between the $\mathrm{O}$ factor and creativity. Besides, the action facet of the former factor was a negative predictor of creativity (TTCT). In this sense, De Caroli and Sagone (2009) did not find a relationship between the $\mathrm{O}$ factor and creativity when 
Table 3

CAPI Factors and Facets as creativity predictors (TTCT and CPS)

\begin{tabular}{|c|c|c|c|}
\hline \multirow[b]{2}{*}{ CAPI Factors } & \multicolumn{3}{|c|}{ TTCT CPS Hetero-report $(N=356)$ CPS Self-report $(N=157$} \\
\hline & St. $\beta$ & St. $\beta$ & St. $\beta$ \\
\hline Neuroticism & -.13 & $-.20^{* * *}$ & -.15 \\
\hline Extraversion & -.30 & .06 & $.24^{* *}$ \\
\hline Restraint & -.01 & -.00 & -.14 \\
\hline Meticulousness & .02 & $.12^{*}$ & $.26^{* *}$ \\
\hline Openness & .03 & -.03 & -.14 \\
\hline$R^{2}$ & .02 & .05 & .14 \\
\hline$F$ value & 1.31 & $3.83^{* *}$ & $4.67^{* *}$ \\
\hline \multicolumn{4}{|l|}{ CAPI Facets } \\
\hline Competence (N-) & $.22^{* * *}$ & $.32^{* * *}$ & $.32^{* * *}$ \\
\hline Self-criticism (N) & $.13^{*}$ & .07 & $.24^{* *}$ \\
\hline Vulnerability (N) & $-.19 * *$ & -.11 & -.07 \\
\hline Anxiety (N) & .03 & .01 & -.07 \\
\hline $\begin{array}{l}\text { Gregarious feeling and Positive } \\
\text { emotion (E) }\end{array}$ & .09 & $.13^{*}$ & $.18^{*}$ \\
\hline Confidence (E) & -.09 & -.05 & .14 \\
\hline Excitement seeking ( $\mathrm{R}$-) & .01 & -.02 & $.19^{*}$ \\
\hline Adaptability (R) & .09 & -.04 & .02 \\
\hline Activity (R -) & .09 & .02 & .01 \\
\hline Order (M) & -.07 & .00 & -.08 \\
\hline Organization (M) & .11 & .08 & $.20^{*}$ \\
\hline Responsibility (M) & -.07 & .00 & .08 \\
\hline Actions (O) & $-.16^{* * *}$ & -.11 & -.07 \\
\hline Innovation $(\mathrm{O})$ & .05 & -.05 & .45 \\
\hline$R^{2}$ & .12 & .14 & .32 \\
\hline$F$ value & $3.44^{* * *}$ & $3.82^{* * *}$ & $4.79^{* * *}$ \\
\hline
\end{tabular}

Notes: ${ }^{*} p<.05 .{ }^{* *} p<.01 .{ }^{* * *} p<.001$.

working with children. Furthermore, a few studies in adults have showed a negative relationship between $\mathrm{O}$ and creativity (Batey et al., 2010; Elisondo, Donolo, \& Corbalán, 2009; Martindale \& Dailey, 1996). More specifically, Batey et al. (2010) found a negative relationship between the action facet of the $O$ factor and the tendency to generate new and original ideas; thus, the authors hypothesized as a result, that the action facet focuses on physical actions, while creativity was assessed from the generation of ideas. In the same vein, the present study considers that in the action facet of the $\mathrm{O}$ factor of CAPI, the items do not specifically address components of creativity such as fantasy, originality, fluency, flexibility, thinking-out, creation, but rather wider actions concerning the diversity of interests. Therefore, the child could be creative drawing or building something new, which may not necessarily be related to a desire to discover new places and learn new things, as proposed by CAPI.

\section{Personality and Creativity from CPS}

The results showed that children with less $\mathrm{N}$, greater competency (negative facet of $\mathrm{N}$ ), gregarious feeling and positive emotions (facet of E) and greater M (factor operationalized by CAPI related to order and organization) were perceived by their parents and evaluated by themselves as more creative, innovative and original. In line with these results, studies show that creative people have emotional stability, confidence, an entrepreneurial spirit, and frustration tolerance (Davis et al., 2011; Huidobro, 2002; López Martínez \& Navarro Lozano, 2010). Moreover, the negative emotional states reduce creativity (Amabile, Barsade, Mueller, \& Staw, 2005).

Finally, McCrae (1987) found positive correlations between Conscientiousness (factor operationalized by NEO PI$\mathrm{R}$ and NEO-FFI associated with order and self-discipline) and self-reports of creativity in adults, whereas Huidobro (2002) and Romo (1997) mention persistence, discipline and sustained effort as necessary features of creative people.

Considering the relationship between the Big Five per- 
sonality traits and self-reported creativity, the results show that more extroverted, loquacious and dynamic children who prefer social interaction and companionship and who had a greater capacity for self-criticism (a facet of $\mathrm{N}$ ) tended to assess themselves as more creative. These data are consistent with previous studies (Davis et al., 2011; Furnham \& Bachtiar, 2008; Furnham et al., 2013; López Martínez \& Navarro Lozano, 2010; Werner et al., 2014) where creativity is associated with boldness, freedom, carefree, action, enthusiasm, social relationships and the ability to take risks. Finally, it was found that children who are more excitement-seeking (negative facet of R), i.e., are more daring and like adventure and excitement, evaluated themselves as more creative, original, innovative and open to new experiences. Indeed, several studies show that risk-taking is a characteristic of creative people (Rodríguez Estrada, 2005; Sternberg \& Lubart, 1997).

In summary, the results suggest that most creative children would present less vulnerability and psychological distress, being more independent, competent and emotionally selfregulated to deal with environmental demands.

\section{Strengths and limitations}

The most significant contributions of this study has been the consistently negative relationship found between creativity and the $\mathrm{N}$ factor and the vulnerability facet, as well as the positive relationship between creativity and the competence facet. These results could be considered for the design of intervention programs aiming at promoting creativity, thus strengthening children's competence regarding creative efficacy.

Although this study provides interesting results related to personality and creativity in children, it also has certain limitations. As the results with respect to $\mathrm{O}$ are unclear, it is suggested to further explore this dimension in children. Besides, it would be relevant to include other approaches to assess children's personality. Furthermore, it becomes significant to consider that the organization of the factors and facets of the CAPI is not like other personality inventories that operationalize the Big Five approach, which actually limits the comparison with other studies that have used this model.

Considering that this study was conducted in a Hispanic context, it would be interesting its replication in other cultural contexts. Finally, being that this research was cross-sectional, and considering that the creative potential of children is in development and may change over time, it would be important to pose a longitudinal design for its study.

Specifically, as regards creativity, it would be important to address it from more inclusive approaches that consider both the context and situation of the study, as well as the assessment of the products and creative processes involved, since as previously mentioned, youth and adults samples showed different personality traits when evaluating the artistic, everyday and scientific creativity (Batey \& Furnham, 2006).

Finally, the study focused on the role of individual differences, specifically the personality from the Big Five in children's creativity; it would be relevant for future studies to include other aspects such as motivation, executive functions, intelligence and contexts in particular to explain the complex nature of creativity.

A deeper understanding of childhood personality and its relationship with creativity is crucial to address the needs of students and school teachers. Various studies have shown that personality is in continual development during childhood and adolescence and has a crucial impact on the creative potential of children. Therefore, creative potential also enables the restructuring of personality. Hence, it is important that strategies and objectives in education address the formation of personality and the development of creativity.

\section{Acknowledgements}

We are indebted to all the schools and youngsters who contributed to this study. We are also grateful to the anonymous reviewers for the valuable comments and suggestions.

\section{References}

Amabile, T. M., Barsade, S. G., Mueller, J. S., \& Staw, B. M. (2005). Affect and creativity at work. Administrative Science Quarterly, 50(3), 367-403.

Barron, F., \& Harrington, D. M. (1981). Creativity, intelligence and personality. Annual Review of Psychology, $32,439-476$

Batey, M., Chamorro-Premuzic, T., \& Furnham, A. (2010). Individual differences in ideational behavior: can the big five and psychometric intelligence predict creativity scores? Creativity Research Journal, 22(1), 90-97.

Batey, M., \& Furnham, A. (2006). Creativity, intelligence, and personality: A critical review of the scattered literature. Genetic, Social, and General Psychology Monographs, 132(4), 355-429.

Cattell, R. B. (1950). Personality a systematic theoretical and factual study. New York: McGraw Hill.

Chamorro-Premuzic, T., \& Reichenbacher, L. (2008). Effects of personality and threat of evaluation on divergent and convergent thinking. Journal of Research in Personality, 42(4), 1095-1101.

Costa, P. T., \& McCrae, R. R. (1980). Still stable after all these years: personality as a key to some issues in adulthood and old age. In P. B. Baltes \& O. G. Brim (Eds.), Still stable after all these years: personality as a key to some issues in adulthood and old age (3rd ed., p. 65-102). New York: Academic Press.

Davis, C. D., Kaufman, J. C., \& McClure, F. H. (2011). Non-cognitive constructs and self-reported creativity by domain. The Journal of Creative Behavior, 45(3), 188-202.

De Caroli, M. E., \& Sagone, E. (2009). Creative thinking and big five factors of personality measured in italian schoolchil-dren. Psychological Reports, 105(3), 791803. 
Depaula, P. D., \& Azzollini, S. C. (2013). Análisis del modelo big five de la personalidad como predictor de la inteligencia cultural. PSIENCIA: Revista Latinoamericana de Ciencia Psicológica, 5(1), 35-43.

Dollinger, S., Urban, K., \& James, T. (2004). Creativity and openness: Further validation of two creative product measures. Creative Research Journal, 16(1), 35-47.

Elisondo, R., Donolo, D., \& Corbalán, J. (2009). Evaluación de la creatividad. relaciones con inteligencia y personalidad. Revista iberoamericana de diagnóstico y evaluación psicológica, 28(2), 67-79.

Eysenck, H. J. (1976). The measurement of personality. London: University Park Press.

Feist, G. J. (1998). A meta-analysis of personality in scientific and artistic creativity. Personality and Social Psychology Review, 2(4), 90-309.

Furnham, A., \& Bachtiar, V. (2008). Personality and intelligence as predictors of creativity. Personality and individual differences, 45(7), 613-617.

Furnham, A., Hughes, D. J., \& Marshall, E. (2013). Creativity, ocd, narcissism and the big five. Thinking Skills and Creativity, 10, 91-98.

Garaigordobil, M., \& Pérez, I. (2005). Escala de personalidad creadora: estudio psicométrico exploratorio. Estudios de Psicología, 26(3), 345-364.

Garaigordobil, M., \& Pérez, J. I. (2002). Análisis predictivo y correlacional de la creatividad gráfica y verbal con otros rasgos de la personalidad infantil. Revista de Psicología General y Aplicada, 55, 373-390.

Grinhauz, A. S., \& Solano, A. C. (2014). La evaluación de las virtudes y fortalezas del carácter en niños argentinos: adaptación y va-lidación del inventario de virtudes y fortalezas para niños (IVyF niños). Summa psicológica UST, 11(1), 115-126.

Hoseinifar, J., Siedkalan, M. M., Zirak, S. R., Nowrozi, M., Shaker, A., Meamar, E., \& Ghaderi, E. (2011). An investigation of the relation between creativity and five factors of personality in students. Procedia-Social and Behavioral Sciences, 30, 2037-2041.

Hughes, D. J., Furnham, A., \& Batey, M. (2013). The structure and personality predictors of self-rated creativity. Thinking Skills and Creativity, 9, 76-84.

Huidobro, T. (2002). Una definición de la creatividad a través del estudio de 24 autores seleccionados (Tesis Doctoral, Universidad Complutense de Madrid). Retrieved from http: //eprints.ucm.es/tesis / psi/ucm-t25705.pdf

Kaufman, S. B., Quilty, L. C., Grazioplene, R. G., Hirsh, J. B., Gray, J. R., Peterson, J. B., \& DeYoung, C. G. (2015). Openness to experience and intellect differentially predict creative achievement in the arts and sciences. Journal of personality, 82, 248-258.

Krumm, G. (2012). Recursos asociados a la creatividad infantil: personalidad y contexto en la niñez mediana y tardía (Tesis doctoral inédita). Universidad Adventista del Plata.

Krumm, G., \& Lemos, V. (2011a). Análisis de las propiedades psicométricas de la prueba de figuras del test de pensamiento creativo de Torrance (TTCT). forma B, en la provincia de Entre Ríos, Argentina. In M. C. Richaud de Minzi \& V. Lemos (Eds.), (p. 731-748). Buenos Aires: Editorial Universidad Adventista del Plata.

Krumm, G., \& Lemos, V. (2011b). Estudio exploratorio de las propiedades psicométricas de la escala de personalidad creadora (epc) en su versión heteroevaluación. Revista Interamericana de Psicología, 45, 21-28.

Krumm, G., Lemos, V., \& Arán Filippetti, V. (2014). Factor structure of the torrance tests of creative thinking figural form $b$ in spanish-speaking children: Measurement invariance across gender. Creativity Research Journal, $26,72-81$.

Lemos, V. (2013). La operacionalización de constructos psicológicos en la infancia: dificultades y propuestas de superación. Anuario de Psicología/The UB Journal of Psychology, 43, 189-199.

López Martínez, O., \& Navarro Lozano, J. (2010). Rasgos de personalidad y desarrollo de la creatividad. Anales de Psicología, 26(1), 151-158.

Martindale, C., \& Dailey, A. (1996). Creativity. primary process cognition and personality. Personality and individual differences, 20(4), 409-414.

McCrae, R. R. (1987). Creativity, divergent thinking, and openness to experience. Journal of Personality and Social Psychology, 56(6), 1258-1265.

Reiter-Palmon, R., Illies, J. J., \& Kobe, L. M. (2009). Conscientiousness is not always a good predictor of performance: The case of creativity. International Journal of Creativit and Problem Solving, 19, 27-46.

Rodríguez Estrada, M. (2005). Manual de creatividad. los procesos psíquicos del desarrollo. Sevilla: MAD.

Romo, M. (1997). Psicología de la creatividad. México: Paidós.

Silvia, P. J., Kaufman, J. C., \& Pretz, J. E. (2009). Is creativity domain-specific? latent class models of creative accomplishments and creative self-descriptions. Psychology of Aesthetics, Creativity, and the Arts, 3(3), 139-148.

Silvia, P. J., \& Kimbrel, N. A. (2010). A dimensional analysis of creativity and mental illness: Do anxiety and depression symptoms predict creative cognition, creative accomplishments, and creative self-concepts? Psychology of Aesthetics, Creativity, and the Arts, 4(1).

Silvia, P. J., Nusbaum, E. C., Berg, C., Martin, C., \& O’Connor, A. (2009). Openness to experience, plasticity, and creativity: Exploring lower-order, higher-order, and interactive effects. Journal of Research in Personality, 43(6), 1087-1090.

Simkin, H., \& Etchevers, M. (2014). Religiosidad, espiritualidad y salud mental en el marco del modelo de los cinco factores de la personalidad. Acta Psiquiátrica y Psicológica de América Latina, 60, 265-275. 
Sternberg, R. J., \& Lubart, T. I. (1997). La creatividad en una cultura conformista. un desafio a las masas. Barcelona: Paidos.

Torrance, P., Ball, O., \& Safter, H. T. (1992). Torrance test of creative thinking. streamlined scoring guide figural a and $b$. Illinois: Scholastic Testing Service.

Werner, C. H., Tang, M., Kruse, J., Kaufman, J. C., \& Spörrle, M. (2014). The chinese version of the revised creativity domain questionnaire (CDQ-R): First evi-dence for its factorial validity and systematic association with the big five. The Journal of Creative Behavior, 4, 254-275. 